\title{
ANALISIS RASIO KEUANGAN DALAM MEMPREDIKSI PROFIT GROWTH PADA PERUSAHAAN MANUFAKTUR SEKTOR 5
}

\author{
Bayu Pasupati \\ Fakultas Ekonomi dan Bisnis, Universitas Warmadewa \\ Email: bayupasupati7@gmail.com
}

\begin{abstract}
ABSTRAK
Penelitian ini bertujuan untuk mengkaji dan menganalisis dalam memprediksi profit growth secara empiris, yang berfokus pada perusahaan manufaktur di Sektor 5 dengan menggunakan rasio keuangan. Rasio keuangan menggunakan profitabilitas dengan ROE, rasio likuiditas dengan CR, rasio leverage dengan DER, rasio aktivitas dengan TATO, dan rasio pasar modal dengan EPS serta kemampuan variabel moderasi yang terdiri dari kepemilikan manajerial, proporsi komisaris independen, dan komite audit. Jenis penelitian ini menggunakan metode analisis kuantitatif asosiatif, yang bertujuan untuk menguji hipotesis. Penelitian ini melibatkan 84 sampel perusahaan Sektor 5 Manufaktur selama tahun 2015-2017. Teknik analisis data menggunakan uji asumsi klasik, analisis regresi linier berganda, dan moderasi. Penelitian ini menunjukkan bahwa rasio profitabilitas, rasio likuiditas, dan rasio aktivitas berpengaruh signifikan. Sebaliknya, rasio leverage dan rasio pasar modal tidak berpengaruh signifikan terhadap profit growth. Rasio profitabilitas tidak dimoderasi oleh kepemilikan manajerial, dan komite audit memoderasi proporsi komisaris independen. Rasio likuiditas tidak dimoderatori oleh kepemilikan manajerial sedangkan dimoderatori oleh proporsi komisaris independen dan komite audit. Rasio leverage tidak dimoderatori oleh kepemilikan manajerial, proporsi komisaris independen, dan komite audit. Rasio aktivitas dimoderatori oleh kepemilikan manajerial dan komite audit sedangkan tidak dimoderasi oleh komisaris independen. Rasio pasar modal hanya dimoderasi oleh kepemilikan manajerial sedangkan tidak dimoderasi oleh proporsi komisaris independen dan komite audit yang semuanya diuji tentang profit growth.
\end{abstract}

Kata kunci: profit growth, ROE, CR, TATO

\begin{abstract}
This study aims to examine and analyze in predicting profit growth empirically, which focuses on manufacturing companies in Sector 5 using financial ratios. Financial ratios use profitability with $R O E$, liquidity ratios with $C R$, leverage ratios with DER, activity ratios with TATO, and capital market ratios with EPS and the ability to moderate variables consisting of managerial ownership, the proportion of independent commissioners, and the audit committee. This type of research uses the associative quantitative analysis method, which aims to test the hypothesis. This study involved 84 samples of Sector 5 Manufacturing companies during 2015-2017. The data analysis technique used classical assumption test, multiple linear regression analysis, and moderation. This study indicates that profitability ratios, liquidity ratios, and activity ratios have a significant effect. In contrast, leverage ratios and capital market ratios have no significant effect on profit growth. Profitability ratios are not moderated by managerial ownership, and the audit committee moderates the proportion of independent commissioners. The liquidity ratio is not moderated by managerial ownership while moderated by the proportion of independent commissioners and audit committees. The leverage ratio is not moderated by either managerial ownership, the proportion of independent commissioners, and the audit committee. The activity ratio is moderated by managerial ownership and the audit committee while not moderated by independent commissioners. Capital market ratios are moderated only by managerial ownership while not moderated by the proportion of independent commissioners and audit committees which are all tested concerning profit growth.
\end{abstract}

Kata kunci: profit growth, $R O E, C R$, TATO 


\section{PENDAHULUAN}

Keberadaan wide world web (WWW) sebagai fungsi protokol sejak awal abad ke-19 teknologi web dalam regenerasi versi 2.0 (web 2.0) oleh (Dholakia \& Uusitalo, 2002), ini menjadikan tools sebagai gate atas peluang baru dalam pelaku bisnis dalam konteks $e$ commerce (Saragih \& Husain, 2012). Peran ini digunakan oleh manusia sebagai salah satu resource penting bagi perusahaan, dimana manusia tidak terlepas dari kebutuhan pokok, salah satunya adalah pangan yang menjadi bidang bisnis dan selalu dibutuhkan oleh perusahaan yang masuk dalam kategori barang konsumsi. Pertumbuhan industri Fast Moving Consumer Goods (FMCG) di Indonesia cukup fluktuatif. Informasi yang terkandung dalam angka akuntansi akan berguna jika laba yang sesungguhnya berbeda dengan laba yang diharapkan (expected earning) (Putra, Mahaputra, \& Pasupati, 2021). Berikut adalah grafik profit growth industri FMCG di Indonesia (Gunawan, 2018), dijelaskan pada Gambar 1 berikut ini:

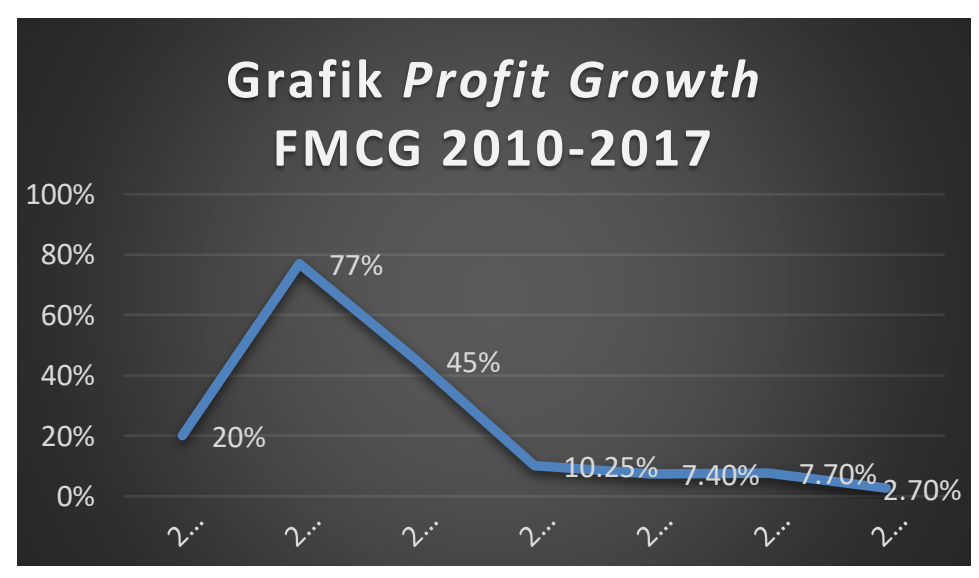

Gambar 1 Grafik Profit Growth FMCH 2010-2017 Sumber: CNBC Indonesia (Diolah, 2020)

Konsumsi FMCG pada tahun 2013 dan 2014 terlihat melemah yang disebabkan oleh kenaikan harga BBM pada Juni 2013 dan kenaikan tarif listrik yang dilaporkan oleh CNBC Indonesia, kedua kebijakan ini mempengaruhi biaya produksi perusahaan. Pada tahun 2017, industri ini hanya tumbuh 2,7 persen dibandingkan pertumbuhan Compound Annual Growth Rate (CAGR) sebesar 11 persen dari tahun 2003 hingga 2017 (Muamar, 2018). Menurut rilis Bisnis Tempo.Co pada triwulan II tahun 2018, pertumbuhan industri makanan dan minuman mencapai 867 persen atau melampaui pertumbuhan ekonomi nasional sebesar 5,27 persen sehingga industri makanan dan minuman mampu memberikan kontribusi tertinggi terhadap PDB non-industri pengolahan migas hingga 35,87 persen (Paramaesti, 2018). Asosiasi Pengusaha Indonesia semakin optimis bahwa industri manufaktur akan meningkat pada 
bulan-bulan berikutnya seperti indikator indeks manajer pembelian pada bulan Agustus 2018 yang naik hingga level 51,9 dibandingkan Juli 2018 sebesar 50,5 (Antara, 2018). Kenaikan indeks manajer pembelian ini mengindikasikan bahwa operasional manufaktur di Indonesia berkembang lebih cepat dibandingkan dengan bulan-bulan sebelumnya.

Kondisi manufaktur makanan dan minuman yang kian bertumbuh menarik minat para investor. Pada kuartal I/2018, industri manufaktur mencatatkan nilai ekspor sebesar USD32 miliar atau naik 4,5\% dibanding capaian pada periode yang sama tahun lalu di angka USD 30,6 miliar (Kementerian Perindustrian RI, 2018). Sebelum mengambil keputusan investasi tentunya investor harus mempertimbangkan berbagai informasi baik keuangan maupun non keuangan. Informasi keuangan ini dapat dilihat dari laporan keuangan perusahaan yang telah diaudit. Akuntan publik memiliki peran sentral atas output informasi keuangan dalam penetapan biaya audit untuk menghasilkan opini audit dari pihak-pihak yang berkepentingan dengan suatu kontrak (Husain \& Syniuta, 2020). Di sisi lain, Horigan (1965), Penman (1991), dalam Tuasikal, 2002) menyatakan kondisi keuangan perusahaan saat ini dan masa depan diperlukan suatu alat yang berguna untuk memprediksi adanya kesulitan keuangan perusahaan yang menjadi panduan bagi investor mengenai kinerja aktivitas pada masa lalu dan masa depan (Pasupati, 2020).

Rasio keuangan digunakan sebagai alat membantu investor menghindari saham yang akan memiliki kegiatan korporasi yang signifikan (Ak, Dechow, Sun, \& Wang, 2013). Rasio keuangan utama yang dapat dilibatkan diantaranya rasio profitabilitas (return on equity $R O E$ ), rasio likuiditas (current ratio), leverage ratio (debt to equity ratio), rasio aktivitas (total assets turnover), rasio pasar modal (earning per share) (Herawati, 2017). Kontrak keagenan dalam teori agensi dapat dipahami bahwa investor tidak akan ragu membayar harga premium untuk saham perusahaan yang memiliki mekanisme corporate governance. Kesiapan Indonesia dalam menghadapi Masyarakatt Ekonomi ASEAN (MEA) sejak tahun 2015 memerlukan suatu kerjasama membentuk suatu komunitas berdasarkan "Roadmap Tata Kelola Perusahaan Indonesia" pada laporan OJK sehingga diperlukan seperangkat perjanjian atau kerjasama dalam bidang tata-kelola perusahaan atau populer yang diistilahkan dengan istilah Good Corporate Governance (Driharsanto \& Husain, 2016). Di samping itu, kebutuhan akan akuntan profesional menuntut adanya transparansi dan akuntabilitas baik di sektor Swasta maupun Pemerintah dalam kerangka AFTA 2015 (Ridwan \& Husain, 2017), dimana tuntutan di atas juga termasuk dalam prinsip yang tertuang dalam corporate governance. Tata kelola perusahaan yang baik (good corporate governance - GCG) merupakan salah satu faktor non-keuangan yang penting untuk dianalisis dan menjadi katalis 
dalam mengukur kinerja perusahaan. Beberapa elemen tata kelola ini yaitu proporsi komisaris independen, kepemilikan manajerial, komite audit, dan mekanisme lainnya yang pengindikasikan peran struktur dan mekanisme GCG. Di samping itu, laporan keuangan akan memiliki relevansi, tepat waktu dan kecepatan dan juga harus diaudit dalam rilisnya tidak terlepas dari serangkaian proses dan keterlibatan lingkungan organisasi itu sendiri (Panglipurningrum \& Husain, 2021).

Menurut rilis dari newsroom: RSM International Association, skor emiten Indonesia tahun 2017 berhasil naik ke posisi 70,59 dari skor rata-rata tahun 2015 di posisi 62,88 untuk peringkat ASEAN Corporate Governance Scorecards (ACGS). Namun, meskipun nilai Indonesia meningkat, praktik GCG di Indonesia masih rendah karena 500 perusahaan publik yang terdaftar di Bursa Efek Indonesia; diantaranya hanya 100 emiten yang masuk dalam pemeringkatan ACGS tersebut (Pertiwi, 2018). Atau dengan kata lain, penerapan GCG di Indonesia masih perlu menjadi agenda mendatang yang harus diselesaikan untuk menarik minat investor terhadap perusahaan-perusahaan di Indonesia, khususnya kelompok perusahaan keluarga menguasai 54 persen kapitalisasi pasar (OECD, 2017). Di samping itu, Indonesia juga menghadapi era industry 4.0 dalam kurun 5 (lima tahun terakhir dengan konsep pemanfaatan basis teknologi di belahan dunia manapun yang tidak dapat dihindari oleh individu dan organisasi siapapun dan apapun (Sarwani \& Husain, 2021).

Beberapa penelitian terdahulu juga telah membuktikan bahwa rasio keuangan berguna bagi investor untuk mendapatkan jaminan keamanan investasi dan kemampuan investasi untuk menghasilkan arus kas di masa yang akan datang (Daniel, 2015). Rasio keuangan dapat digunakan untuk memprediksi laba dan perusahaan dan mengurangi kecenderungan untuk mengambil keputusan yang berisiko tinggi melalui GCG yang mempunyai kinerja keuangan yang lebih baik (Zagorchev \& Gao, 2015). Praktek tata kelola sangat penting untuk memaksimalkan harga saham dan kinerja perusahaan (Khan \& Ibrahim, 2017). Tata kelola perusahaan dapat menjadi moderator positif atau negatif yang dapat meningkatkan dan mempercepat kinerja, return on assets, return on equity dan Real Estate Investment Trust (REIT) return dan mengurangi biaya keagenan (Chong, Ting, \& Fah Fah, 2018). Dalam konteks sektor industri dalam mencapai output kinerja perusahaan, prosedur alternatif diperlukan organisasi untuk memperoleh keyakinan yang memadai dengan merencanakan perhitungan dengan baik dan menganalisis risiko yang signifikan (Pasupati \& Husain, 2020). Penelitian di Indonesia yang menguji tingkat penjualan memiliki pengaruh terhadap profit growth sementara ukuran perusahaan tidak dapat memperkuat .atau memperlemah hubungan antara variabel independen dan variabel dependen (Lim \& Rice, 2016). GCG dan 
Profitabilitas untuk memprediksi determinan tertentu yaitu (Driharsanto \& Husain, 2016) membuktikan ukuran dewan direksi dan proporsi komisaris independen dalam mekanisme GCG serta profitabilitas berpengaruh negatif dan signifikan. Akan tetapi, kepemilikan manajerial, ukuran komite audit, proporsi komite audit independen dan frekuensi pertemuan komite audit tidak berpengaruh signifikan. Sementara pada penelitian (Yunita, 2012) yang menyatakan bahwa komisaris independen tidak berpengaruh signifikan sementara kepemilikan institusional berpengaruh signifikan yang keduanya menguji faktor profitabilitas dalam konteks biaya utang serta board diversity juga tidak berpengaruh dalam memprediksi kinerja perusahaan (Fransisca, 2013).

Teori keagenan merupakan teori yang diperkenalkan oleh Jensen dan Meckling pada tahun 1976, mengungkapkan hubungan antara pemilik (principal) dan manajemen (agent). Teori agensi menjadi cabang dari games theory yang mempelajari desain kontrak untuk memotivasi agen rasional untuk bertindak atas nama prinsipal ketika kepentingan agen akan bertentangan dengan mereka (Scott, 2015, hal. 340). Corporate governance merupakan mekanisme yang berdasarkan pada agency theory. Implementasi tata kelola ini harus memberikan kepercayaan kepada manajemen dalam mengatur kepentingan pemegang saham dan pemilik perusahaan semakin percaya bahwa agent tidak akan melakukan kecurangan dan meminimalkan konflik kepentingan serta mengurangi agency cost. Upaya minimalisasi agency cost dapat dilakukan dengan membuat kontrak antara manajemen dan karyawan. Tetapi konflik tidak dapat dihilangkan sepenuhnya hanya dengan membuat kontrak. Dengan tidak adanya kontrak yang lengkap, tata kelola perusahaan memainkan peran penting untuk memitigasi konflik.

Signalling Theory menjelaskan bahwa perusahaan mempunyai dorongan untuk memberikan informasi kepada pihak eksternal perusahaan. Pemberian sinyal ini dilakukan untuk mengurangi asimetri informasi.Perusahaan mengharapkan manajer untuk dapat meningkatkan pertumbuhan yang tinggi di masa depan, maka perusahaan akan memberikan sinyal kepada investor melalui akun-akun pada laporan keuangan (Godfrey, Hodgson, Tarca, Hamilton, \& Holmes, 2010, hal. 276). Sinyal yang diberikan dalam bentuk informasi kepada pihak luar ini bertujuan untuk menunjukkan bahwa perusahaan memiliki kinerja yang lebih baik daripada perusahaan lainnya. Sinyal positif akan mendorong calon investor melakukan investasi pada perusahaan tersebut.

Laba menjadi salah satu pengukuran aktivitas operasi. Perusahaan yang memiliki laba yang relatif stabil memungkinkan untuk memprediksi besarnya estimasi laba di masa yang akan datang dan perusahaan ini biasanya akan membayar persentase yang lebih tinggi dari labanya 
sebagai dividen di bandingkan perusahaan dengan laba berfluktuasi (Hery, 2013). Perusahaan dapat mengelola penjualan yang dilakukan untuk memperoleh laba yang ditunjukkan dengan persentase kenaikan laba yang diperoleh suatu perusahaan.

Rasio keuangan adalah hubungan yang mengindikasi aktivitas industry yang membantu individu memahami kinerja perusahaan dibandingkan dengan pesaingnya dan sering digunakan untuk mengukur kinerja. Pemegang saham dan kreditor menggunakan analisis laporan keuangan untuk mengevaluasi daya tarik perusahaan sebagai sebuah investasi dengan mengetahui kemampuan perusahaan dalam memenuhi kewajiban jangka pendek dan panjang (Al Attar, 2016). Rasio profitabilitas yang digunakan adalah ROE agar selaras dengan leverage ratio (DER) dalam memprediksi laba (Putra, Lahindah, \& Rismandi, 2014). ROE digunakan untuk mengukur keefektifan perusahaan dalam menggunakan modal yang tersedia. Perusahaan yang memiliki $R O E$ yang tinggi memungkinkan perusahaan untuk menghasilkan profit yang lebih di masa yang akan datang. Profit juga merupakan informasi penting bagi investor dalam pertimbangan memutuskan berivestasi pada suatu perusahaan. Rasio likuiditas menjadi diperlukan dalam memprediksi kinerja perusahaan, khususnya dalam industri makanan dan minuman (Batchimeg, 2017) Rasio yang digunakan dalam penelitian ini adalah Current Ratio (CR) karena menggambarkan komposisi aset lancar secara keseluruhan dibandingkan dengan rasio likuiditas lainnya. Penggunaan utang untuk membiayai perusahaan mempengaruhi kelangsungan hidup perusahaan. Terdapat 3 jenis leverage ratio yaitu leverage ratio berdasarkan laporan posisi keuangan, arus kas masa datang dan risiko pasar (Gupta, 2012). Debt to Equity Ratio (DER) sebagai fungsi dari leverage ratio menunjukkan kemampuan perusahaan untuk memenuhi seluruh kewajiban berdasarkan modal yang tersedia. Nilai $D E R>1$ mengindikasikan operasional perusahaan lebih banyak menggunakan hutang daripada ekuitas sehingga perusahaan menanggung cost of capital, bunga dan risiko kebangkrutan ketika Perusahaan tidak dapat menghasilkan arus kas masuk yang cukup untuk menutupi cost of capital (Veronica \& Anantadjaya, 2014). Rasio ini menunjukkan keefektifan penggunaan aset untuk menghasilkan penjualan (Bansal, 2015). Dengan demikian semakin tinggi TATO semakin tinggi penjualan dan keuntungan yang dihasilkan. Meningkatnya nilai EPS berarti semakin banyak keuntungan per lembar saham yang diterima pemegang saham. Earning per share (EPS) digunakan untuk menganalisis risiko dan membandingkan EPS satu perusahaan dengan perusahaan lain. Semakin tinggi nilai, maka semakin tinggi harga saham (Darmadi \& Fakhrudin, 2006).

FCGI (2001) dan OECD (2004) mendefinisikan tata kelola perusahaan sebagai seperangkat peraturan yang menjelaskan hubungan antara pemegang saham, manajemen, kreditur, 
pemerintah, pegawai, pemangku kepentingan internal dan eksternal sehubungan dengan hak dan kewajiban, serta sistem yang langsung mengendalikan perusahaan (Boediono, 2005). Secara umum, tedapat 4 (empat) komponen utama yang diperlukan dalam konsep GCG yaitu (1) Kewajaran adalah melindungi kepentingan minoritas dan pemegang saham lain dari manipulasi yang berlawanan dengan peraturan yang berlaku. (2) Transparansi yaitu memastikan sistem informasi yang terbuka, tepat waktu, jelas dan dapat dibandingkan terkait dengan kondisi keuangan, manajemen perusahaan dan kepemilikan perusahaan. (3) Akuntabilitas melakukan klarifikasi terhadap peran, tanggung jawab dan dukungan untuk memastikan keseimbangan kepentingan manajemen dan pemegang saham yang diawasi oleh dewan komisaris. (4) Tanggung jawab dengan memastikan kepatuhan terhadap peraturan sebagai refleksi nilai sosial (Sulistyanto, 2014).

Menurut Munisi, et.al (2014) bahwa struktur dewan memainkan peran sentral dalam tata kelola internal perusahaan, mereka adalah salah satu mekanisme tata kelola perusahaan yang paling penting dalam pengembangan ekonomi. Sistem dewan yang digunakan di Indonesia adalah two-tier board system. Berdasarkan Peraturan Otoritas Jasa Keuangan (OJK) Nomor 21/POJK.04/2015 tentang Penerapan Pedoman Tata Kelola Perusahaan Terbuka, perusahaan terbuka wajib mematuhi tata kelola perusahaan dan jika tidak memenuhi perusahaan terbuka harus menjelaskan alasan yang mendasari.

Beberapa fenomena dan gap penelitian di atas memberikan gambaran bahwa penerapan GCG di Indonesia masih rendah, dan adanya dinamikan tren konsumen yang cepat membuat pertumbuhan industri barang konsumsi berfluktuasi. Kondisi yang berfluktuasi ini disikapi berbeda untuk setiap perusahaan sehingga tidak semua perusahaan maufaktur, khususnya Sektor Industri Barang Konsumsi, yang selanjutnya disebut dengan "Sektor 5") memiliki pertumbuhan laba yang sejalan dengan kondisi yang terjadi di level industri. Dengan demikian, investor harus mempertimbangkan berbagai informasi sebelum mengambil keputusan investasi. Berdasarkan penelitian sebelumnya, penting untuk diuji lebih lanjut elemen corporate governance yang secara spesifik dalam menganalisis hubungan antara rasio keuangan terhadap profit growth. Penelitian ini bertujuan untuk mengkaji dan menganalisis dalam memprediksi profit growth secara empiris yang berfokus pada perusahaan manufaktur Sektor 5.

Hipotesis adalah jawaban sementara terhadap rumusan masalah penelitian, dimana rumusan masalah penelitian (Sugiyono, 2017, p. 95). Hipotesis dikembangkan untuk menjawab tujuan penelitian dan sangat penting diuji untuk menjawab hasilnya secara empiris (Supranto \& Limakrisna, 2019, p. 4). Framework disusun untuk mempermudah paradigma berpikir yang 
diturunkan menjadi suatu model. Menurut Sari (2018), model dapat diartikan sebagai karakteristik utama atau turunan atas pengambilan keputusan yang sistematis untuk menggambarkan fenomena atas suatu objek (Zailani, Husain, \& Budiyantara, 2020). Parameter-parameter objek penelitian ini dikonstruksikan dalam bentuk, struktur, isi, dan makna yang dibatasi dalam sebuah model (Husain, 2019). Oleh karena itu, pada setiap penyusunan paradigma penelitian harus didasarkan pada kerangka berfikir yang diturunkan menjadi model penelitian. Secara teoritis perlu dijelaskan hubungan antar variabel independen dan dependen, jika dalam penelitian ada variabel moderator dan intervening, maka juga perlu dijelaskan, mengapa variabel itu ikut dilibatkan dalam penelitian (Sugiyono, 2017, p. 60). Hipotesis alternatif yang dirumuskan pada penelitian ini yaitu:

$\mathrm{H}_{1}$ dinyatakan sebagai rasio profitabilitas (ROE) yang berpengaruh terhadap profit growth, dimana sebelum mengambil keputusan untuk melakukan investasi pada suatu perusahaan, calon investor tentunya ingin mengetahui imbalan yang akan diterima atas modal yang diberikan. Perusahaan yang memiliki ROE yang tinggi memungkinkan perusahaan untuk menghasilkan profit yang lebih di masa yang akan datang. Investor melihat informasi ROE tersebut sinyal dalam memutuskan berivestasi pada suatu perusahaan atau tidak.

$\mathrm{H}_{2}$ dinyatakan sebagai rasio likuiditas (CR) yang berpengaruh terhadap profit growth, dimana current ratio merupakan alat untuk mengukur kemampuan perusahaan dalam memenuhi kewajiban finansial jangka pendeknya. Tingkat CR yang tinggi mengindikasikan utang jangka pendek dapat dilunasi, tetapi apabila terlalu tinggi dapat berakibat pada modal kerja yang tidak efisien. Apabila CR sama atau lebih dari rata-rata industri, maka perusahaan dapat dikatakan perusahaan yang likuid, dan sebaliknya, apabila lebih kecil dari rata-rata industri yang telah ditentukan, maka perusahaan tersebut dapat dikatakan likuid. Perusahaan yang likuid dapat memutar modal kerja dalam jangka pendek lebih baik sehingga meningkatkan profit growth.

$\mathrm{H}_{3}$ dinyatakan sebagai leverage ratio (DER) yang berpengaruh terhadap profit growth, dimana perusahaan menentukan struktur modal berdasarkan manfaat dan biaya yang melekat pada pembiayaan dengan utang atau modal. Perusahaan yang menggunakan lebih banyak utang daripada modal mengindikasikan bahwa Perusahaan tersebut memiliki laba yang lebih tinggi karena dapat melakukan ekspansi dan membayar bunga pinjaman. Namun keputusan untuk menggunakan utang atau modal juga dipengaruhi oleh asimetri informasi yang terjadi, keputusan yang diambil dapat menguntungkan agen dan merugikan principal. Semakin tinggi DER menunjukkan perusahaan lebih banyak menggunakan utang untuk membiayai perusahaan. 
$\mathrm{H}_{4}$ dinyatakan sebagai rasio aktivitas (TATO) yang berpengaruh terhadap profit growth, dimana rasio aktivitas mengukur keefektifan perusahaan dalam menggunakan aset yang dimiliki untuk menghasilkan laba. Semakin tinggi nilai TATO maka semakin efektif perusahaan menggunakan aset untuk menghasilkan laba.

$\mathrm{H}_{5}$ dinyatakan sebagai rasio pasar modal (EPS) yang berpengaruh terhadap profit growth, dimana EPS merupakan komponen pertama yang dilihat oleh calon investor dan pengguna laporan keuangan. EPS menunjukkan seberapa besar keuntungan yang diperoleh investor atau pemegang saham per lembar saham. Semakin tinggi EPS, semakin tinggi pula keberhasilan manajemen dalam mengambil keputusan untuk menyejahterakan pemegang saham.

Selanjutnya tata kelola perusahaan juga berperan dalam memperkuat hubungan antara rasio keuangan dengan profit growth seperti hasil penelitian yang dilakukan oleh (Khan \& Ibrahim, 2017), (Chong, Ting, \& Fah Fah, 2018), yang menunjukkan bahwa corporate governance berpengaruh positif terhadap kinerja perusahaan. Sistem tata kelola perusahaan mengarah kepada kumpulan peraturan dan dorongan yang digunakan pihak manajemen untuk mengarahkan dan mengawasi jalannya kegiatan perusahaan. Nilai perusahaan identik dengan profit growth. Dalam penelitian ini, terdapat 3 variabel corporate governance yang digunakan yaitu proporsi kepemilikan manajerial (KMJ), proporsi komisaris independen (KMI), dan komite audit (KAT) yang dirumuskan menjadi fungsi moderasi dengan pernyataan:

$\mathrm{H}_{6-10}$ yaitu Kepemilikan Manajerial (KMJ) mampu memoderasi masing-masing rasio profitabilitas (ROE), rasio likuiditas (CR), leverage ratio (DER), rasio aktivitas (TATO), dan rasio pasar modal (EPS) secara parsial terhadap profit growth.

$\mathrm{H}_{11-15}$ yaitu proporsi komisaris independen (KMI) mampu memoderasi masing-masing rasio profitabilitas (ROE), rasio likuiditas (CR), leverage ratio (DER), rasio aktivitas (TATO), dan rasio pasar modal (EPS) secara parsial terhadap profit growth.

$\mathrm{H}_{16-20}$ yaitu komite audit (KAT) mampu memoderasi masing-masing rasio profitabilitas (ROE), rasio likuiditas (CR), leverage ratio (DER), rasio aktivitas (TATO), dan rasio pasar modal (EPS) secara parsial terhadap profit growth. 


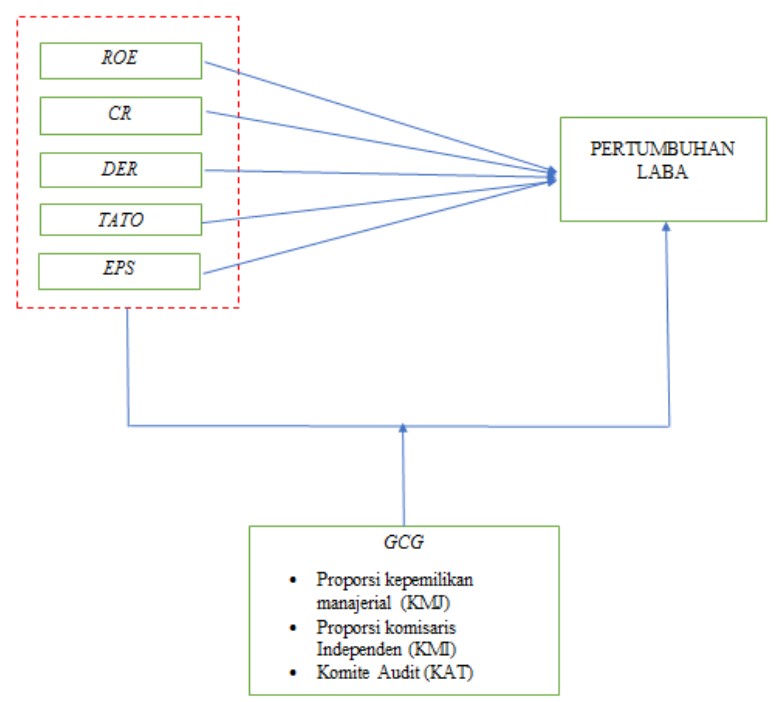

Gambar 2 Model Penelitian: Hubungan antara analisis rasio terhadap profit growth dimoderasi oleh GCG

\section{METODE PENELITIAN}

\section{Jenis Penelitian}

Jenis penelitian ini menggunakan metode analisis kuantitatif asosiatif yaitu metode yang dimaksudkan dalam menjelaskan hubungan kausal dan pengaruh antara variabel-variabel melalui pengujian hipotesis. (Sugiyono, 2017, hal. 11). Penelitian ini menggunakan pendeketan penelitian kuantitatif.

\section{Waktu dan Tempat Penelitian}

Penelitian ini dilaksanakan di Bursa Efek Indonesia (BEI). Objek Penelitian adalah laporan keuangan perusahaan manufaktur Sektor 5 yang sahamnya listing di BEI yang diakses dari www.idx.co.id dan website resmi masing-masing perusahaan.

\section{Target/Subjek Penelitian}

Subjek penelitian melibatkan perusahaan-perusahaan Manufaktur Sektor 5 yang sahamnya aktif listing di pasar bursa. Metode sampling dalam penelitian ini adalah purposive sampling yang mengambil sampel berdasarkan beberapa kriteria yaitu perusahaan yang terdaftar dalam kategori subjek penelitian selama data pengamatan yaitu tahun 2015 - 2017 dan menerbitkan laporan tahunan secara lengkap.

\section{Data, Instrumen, dan Teknik Pengumpulan Data}

Data menggunakan kategori sekunder yang berupa dokementasi yang diperoleh dari hasil studi perpustakaan, baik berupa bahan-bahan bacaan maupun data angka. Instrumen 
penelitian menggunakan laporan tahunan dan laporan keuangan yang diaudit dan dirilis pada website idx.co.id dan Indonesia Capital Market Directory (ICMD). Instrumen yang menjadi objek penelitian ini diukur dengan menggunakan skala Ratio.

\section{Teknik Analisis Data}

Analisis data menggunakan teknik analisis persamaan regresi linier berganda dan moderasi untuk menguji hipotesis yang dilakukan uji asumsi klasik terlebih dahulu melalui uji normalitas data, uji multikolinearitas, uji heteroskedastisitas, dan uji autokorelasi dilakukan pada taraf signifikansi 5 persen. Data dianalisis menggunakan bantuan perangkat lunak SPSS. Adapun persamaan regresi yang dirumuskan adalah:

$$
\begin{aligned}
E B T= & \mathrm{a}+\beta_{1} R O E+\beta_{2} C R+\beta_{3} D E R+\beta_{4} \text { TATO }+\beta_{5} \text { EPS }+\beta_{6} \mathrm{KMJ}+\beta_{7} \mathrm{KMI}+\beta_{8} \mathrm{KAT}+\beta_{9} \\
& \text { KMJ.ROE.CR.DER.TATO.EPS }+\beta_{10} \mathrm{KMI} . \text { ROE.CR.DER.TATO.EPS }+\beta_{11} \\
& \text { KAT.ROE.CR.DER.TATO.EPS }{ }_{+} e
\end{aligned}
$$

dimana:

$$
\begin{array}{ll}
\mathrm{EBT} & =\text { profit growth } \\
\mathrm{a} & =\text { konstanta } \\
\beta & =\text { koefisien regresi } \\
R O E & =\text { rasio profitabilitas } \\
C R & =\text { rasio likuiditas } \\
D E R & =\text { leverage ratio } \\
T A T O & =\text { rasio aktivitas } \\
E P S & =\text { rasio pasar modal } \\
\mathrm{KMJ} & =\text { kepemilikan manajerial } \\
\mathrm{KMI} & =\text { komposisi komisaris independen } \\
\mathrm{KAT} & =\text { komite audit }
\end{array}
$$

KMJ.ROE.CR.DER.TATO.EPS = interaksi antara kepemilikan manajerial dengan ROE, CR, DER, TATO dan EPS

KMI.ROE.CR.DER.TATO.EPS = interaksi antara komposisi komisaris independen dengan $R O E, C R, D E R, T A T O$ dan EPS

KAT.ROE.CR.DER.TATO.EPS = interaksi antara komite audit dengan ROE, CR, DER, TATO dan $E P S$

e $\quad$ error

\section{HASIL PENELITIAN DAN PEMBAHASAN}

\section{Hasil Penelitian}

Hasil penelitian diawali dengan pengujian asumsi klasik ini dilakukan untuk menguji keberartian persamaan regresi yang mensyaratkan bahwa persamaan regresi harus memenuhi kriteria best linear unbiased estimator yaitu data harus mengikuti kurva normal, variabel 
penelitian tidak boleh terjadi multikolinieritas, data dalam penelitian harus terbebas dari autokorelasi, dan data harus homoskedastisitas.

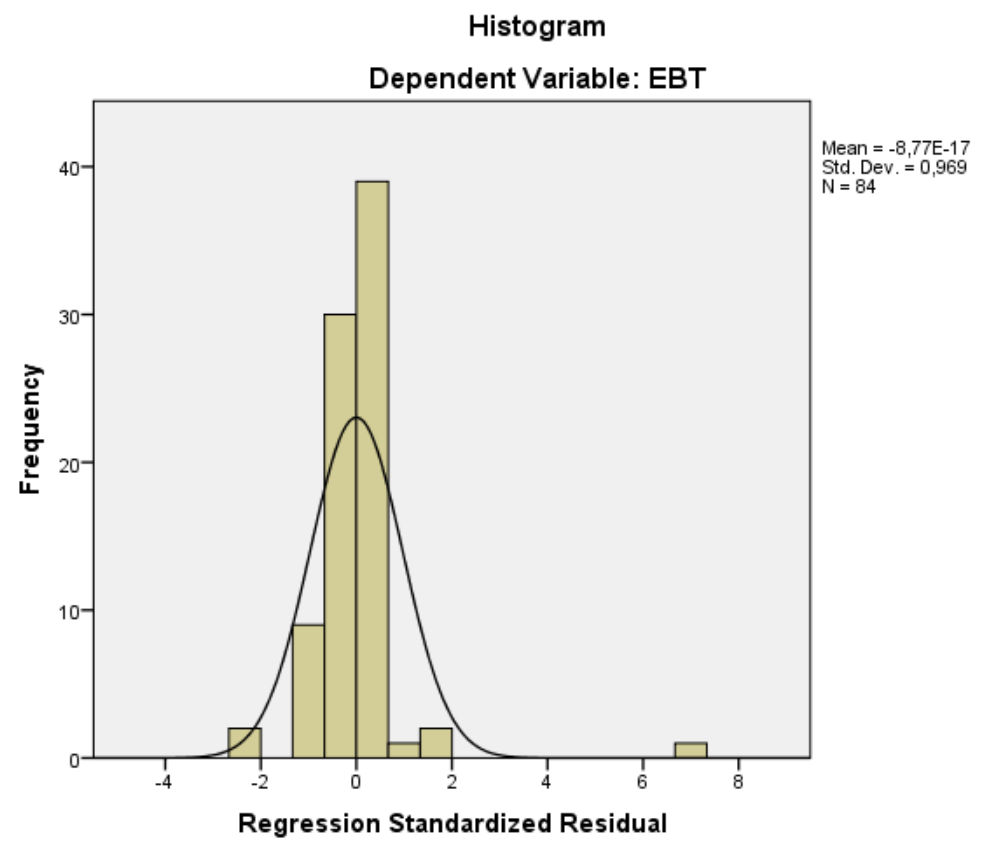

Gambar 3 Histogran Uji Normalitas

Histogram uji normalitas dapat dilihat bahwa distribusi data telah mendekati distribusi normal, yakni distribusi data dengan bell sheped. Tujuan uji multikolinieritas dilakukan untuk menilai apakah model regresi ditemukan adanya korelasi antar variabel bebas (independent).

Tabel 1 Hasil Uji Multikolinieritas Data hubungan antara ROE, CR, DER, TATO, EPS Terhadap EBT (tanpa Moderasi dan dengan Moderasi

\begin{tabular}{|c|c|c|c|c|c|c|c|c|}
\hline \multirow[t]{2}{*}{ Variabel } & \multicolumn{2}{|c|}{ Tanpa Moderasi } & \multicolumn{2}{|c|}{$\begin{array}{l}\text { Dengan Moderasi } \\
\text { KMJ }\end{array}$} & \multicolumn{2}{|c|}{$\begin{array}{l}\text { Dengan } \\
\text { Moderasi KMI }\end{array}$} & \multicolumn{2}{|c|}{$\begin{array}{l}\text { Dengan Moderas } \\
\text { KAT }\end{array}$} \\
\hline & $\begin{array}{l}\text { Nilai } \\
\text { Tolerance }\end{array}$ & $\begin{array}{l}\text { Skor } \\
\text { VIF }\end{array}$ & $\begin{array}{l}\text { Nilai } \\
\text { Tolerance }\end{array}$ & $\begin{array}{l}\text { Skor } \\
\text { VIF }\end{array}$ & $\begin{array}{l}\text { Nilai } \\
\text { Tolerance }\end{array}$ & $\begin{array}{l}\text { Skor } \\
\text { VIF }\end{array}$ & $\begin{array}{l}\text { Nilai } \\
\text { Tolerance }\end{array}$ & $\begin{array}{l}\text { Skor } \\
\text { VIF }\end{array}$ \\
\hline ROE & 0,911 & 1,098 & 0,162 & 6,170 & 0,785 & 1,275 & 0,910 & 1,098 \\
\hline $\mathrm{CR}$ & 0,764 & 1,309 & 0,253 & 3,960 & 0,683 & 1,463 & 0,761 & 1,314 \\
\hline DER & 0,784 & 1,275 & 0,737 & 1,357 & 0,788 & 1,269 & 0,800 & 1,250 \\
\hline TATO & 0,859 & 1,164 & 0,096 & 10,416 & 0,712 & 1,404 & 0,858 & 1,165 \\
\hline EPS & 0,767 & 1,304 & 0,085 & 11,807 & 0,740 & 1,351 & 0,764 & 1,309 \\
\hline
\end{tabular}

Tabel 1 atas uji multikolinieritas menghasilkan collinearity statistics yang terdiri dari nilai tolerance masing-masing untuk ROE, CR, DER, TATO dan EPS serta masing-masing moderasi yang secara umum nilai tolerance lebih besar dari 0,1 kemudian skor VIF dibawah 10, maka dapat disimpulkan data terbebas dari multikolinieritas sehingga data dapat digunakan untuk pengujian selanjutnya. Heteroskedastisitas akan terjadi apabila varian $e i$ (gangguan/disturbance) tidak mempunyai penyebaran yang sama sehingga model yang dibuat kurang efisien. Untuk mengujinya dapat dilakukan dengan Breusch-Pagan-Godfrey. 
Tabel 2 Hasil Uji Heteroskedastisitas Data hubungan antara ROE, CR, DER, TATO, EPS Terhadap EBT (tanpa Moderasi dan dengan Moderasi)

\begin{tabular}{|c|c|c|c|c|c|c|c|c|}
\hline \multirow[t]{2}{*}{ Model } & \multicolumn{2}{|c|}{ Tanpa Moderasi } & \multicolumn{2}{|c|}{$\begin{array}{l}\text { Dengan Moderasi } \\
\text { Variabel KMJ }\end{array}$} & \multicolumn{2}{|c|}{$\begin{array}{l}\text { Dengan Moderasi } \\
\text { Variabel KMI }\end{array}$} & \multicolumn{2}{|c|}{$\begin{array}{l}\text { Dengan Moderasi } \\
\text { Variabel KAT }\end{array}$} \\
\hline & F-statistics & $p$-value & F-statistics & $p$-value & F-statistics & $p$-value & F-statistics & p-value \\
\hline & $\begin{array}{l}2,413 \\
2,32\end{array}$ & 0,043 & $\begin{array}{l}1,201 \\
2,32\end{array}$ & 0,317 & $\begin{array}{l}0,824 \\
2,32\end{array}$ & 0,536 & $\begin{array}{l}2,290 \\
2,32\end{array}$ & 0,053 \\
\hline
\end{tabular}

Kesimpulan Homoskedastisitas Heteroskedastisitas Heteroskedastisitas Homoskedastisitas

Sumber: Data Diolah Penulis (2020)

Tabel 2 atas uji heteroskedastisitas menghasilkan $f$-statistics sebesar 2,413 lebih besar dari Ftable (df1=5; df2=84; $\alpha=5 \%$ ) yaitu 2,32 atau $2,413>2,32$ artinya data bersifat homoskedastisitas atas hubungan antara ROE, CR, DER, TATO, dan EPS terhadap EBT. Selanjutnya dengan menggunakan moderasi variabel KMJ dan Variabel KMI menghasilkan $f$ statistics masing-masing sebesar 1,201 dan 0,824 lebih kecil dari F-table (df1=5; df2=84; $\alpha=5 \%$ ) yaitu 2,32 atau 1,$201 ; 0,824<2,32$ artinya data bersifat heteroskedastisitas atas hubungan antara ROE, CR, DER, TATO, dan EPS terhadap EBT yang dimoderasi oleh proporsi kepemilikan manajerial dan proporsi kepemilikan independen. Akan tetapi, dengan menggunakan moderasi variabel KAT menghasilkan $f$-statistics sebesar 2,290 lebih besar dari F-table (df1=5; df2=84; $\alpha=5 \%$ ) yaitu 2,32 atau $2,290>2,32$ artinya data bersifat homoskedastisitas atas hubungan antara ROE, CR, DER, TATO, dan EPS terhadap EBT yang dimoderasi oleh komite audit.

Tabel 3 Hasil Uji Autokorelasi Data hubungan antara ROE, CR, DER, TATO, EPS Terhadap EBT (tanpa Moderasi dan dengan Moderasi)

\begin{tabular}{|c|c|c|c|c|c|c|c|}
\hline \multirow{2}{*}{\multicolumn{2}{|c|}{ Tanpa Moderasi }} & \multirow{2}{*}{\multicolumn{2}{|c|}{$\begin{array}{l}\text { Dengan Mo } \\
\text { Variabel KMJ }\end{array}$}} & \multirow{2}{*}{\multicolumn{2}{|c|}{$\begin{array}{l}\text { Dengan Mo } \\
\text { Variabel KMI }\end{array}$}} & \multirow{2}{*}{\multicolumn{2}{|c|}{$\begin{array}{l}\text { Dengan Moderasi } \\
\text { Variabel KAT }\end{array}$}} \\
\hline & & & & & & & \\
\hline $\begin{array}{l}d W \\
\text { score }\end{array}$ & $\begin{array}{l}\text { Nilai diantara } \\
\text { dU dan 4-dU }\end{array}$ & $\begin{array}{l}d W \\
\text { score } \\
\end{array}$ & $\begin{array}{c}\text { Nilai diantara } \\
\text { dU dan 4-dU }\end{array}$ & $\begin{array}{l}d W \\
\text { score } \\
\end{array}$ & $\begin{array}{l}\text { Nilai diantara } \\
\text { dU dan 4-dU }\end{array}$ & $d W$ score & $\begin{array}{l}\text { Nilai di antara } \\
\text { dU dan 4-dU }\end{array}$ \\
\hline 2,172 & $\mathrm{Ya}$ & 2,204 & Ya & 2,206 & $\mathrm{Ya}$ & 2,170 & $\mathrm{Ya}$ \\
\hline
\end{tabular}

Tabel 3 atas uji autokorelasi menghasilkan nilai Durbin Watson (dW) masing-masing 2,172; 2,204; 2,206 dan 2,170 yang berada diantara (dU < dW < 4-dU) $(\mathrm{k}=5 ; \mathrm{n}=85)$, du = 1,776, atau $(1,776<\mathrm{dW}<4-1,776)$ yaitu $(1,776<\mathrm{dW}<2,224)$, artinya disimpulkan semua hubungan di atas tidak terjadi autokorelasi dan dapat digunakan untuk pengujian selanjutnya. Hasil persamaan regresi dan uji hipotesis secara parsial dirangkum pada tabel berikut ini:

Tabel 4 Hasil Uji Hipotesis Hubungan antara ROE, CR, DER, TATO, EPS Terhadap EBT (tanpa Moderasi dan dengan Moderasi)

\begin{tabular}{|c|c|c|c|c|c|c|c|}
\hline \multirow[t]{2}{*}{ Model } & \multicolumn{2}{|c|}{ Tanpa Moderasi } & \multicolumn{2}{|c|}{$\begin{array}{l}\text { Dengan Moderasi } \\
\text { Variabel KMJ }\end{array}$} & \multicolumn{2}{|c|}{$\begin{array}{l}\text { Dengan Moderasi } \\
\text { Variabel KMI }\end{array}$} & $\begin{array}{l}\text { Dengan Moderasi } \\
\text { Variabel KAT }\end{array}$ \\
\hline & $\begin{array}{l}\text {-statistics } \\
\mathrm{df}=80 ; \alpha 5 \%\end{array}$ & $p$-value & $\begin{array}{l}\text { t-statistics } \\
\mathrm{df}=80 ; \alpha 5 \%\end{array}$ & $p$-value & $\begin{array}{l}\text { t-statistics } \\
\mathrm{df}=80 ; \alpha 5 \%\end{array}$ & $p$-value & $\begin{array}{l}\text { t-statistics } \\
\mathrm{df}=80 ; \alpha 5 \%\end{array}$ \\
\hline
\end{tabular}




\begin{tabular}{lllllllll}
\hline & & \multicolumn{7}{c}{ t-table $=\mathbf{1 , 6 6}$} \\
\hline Constant & $-1,195$ & 0,236 & 0,952 & 0,344 & $-0,793$ & 0,430 & $-1,195$ & 0,236 \\
ROE & 2,172 & 0,000 & 0,021 & 0,983 & 1,156 & 0,251 & 1,759 & 0,000 \\
CR & 2,767 & 0,007 & 0,837 & 0,405 & 2,323 & 0,023 & 2,731 & 0,008 \\
DER & $-0,561$ & 0,576 & 0,658 & 0,512 & $-0,457$ & 0,649 & $-0,518$ & 0,606 \\
TATO & $-1,674$ & 0,006 & $-1,949$ & 0,005 & $-1,529$ & 0,130 & $-1,229$ & 0,223 \\
EPS & $-0,724$ & 0,471 & 1,744 & 0,003 & $-0,675$ & 0,502 & $-0,824$ & 0,413 \\
\hline
\end{tabular}

Sumber: Data Diolah Penulis (2020)

Tabel 4 atas uji hipotesis menghasilkan $t$-statistics atas ROE terhadap EBT sebesar 2,172 (sig. 0,000), artinya berpengaruh signifikan $\left(\mathrm{H}_{1}\right.$ diterima) sementara ROE terhadap EBT dengan moderasi variabel kepemilikan manajerial dan proporsi komisaris independen masing-masing memiliki t-statistics sebesar 0,021; 1,156 < 1,66 artinya tidak signifikan $\left(\mathrm{H}_{6} ; \mathrm{H}_{11}\right.$ ditolak) karena kurang dari t-table. Di sisi lain, ROE terhadap EBT dengan moderasi variabel komite audit memiliki t-statistics sebesar 1,7591>1,66 artinya signifikan $\left(\mathrm{H}_{16}\right.$ diterima, dengan sig. 0,000). Nilai t-statistics atas CR terhadap EBT sebesar 2,767 (sig. 0,007), artinya berpengaruh signifikan ( $\mathrm{H}_{2}$ diterima) sementara $\mathrm{CR}$ terhadap EBT dengan moderasi variabel kepemilikan manajerial memiliki t-statistics sebesar 0,837 artinya tidak signifikan $\left(\mathrm{H}_{7}\right.$ ditolak) karena kurang dari t-table. Di sisi lain, $\mathrm{CR}$ terhadap EBT dengan moderasi variabel proporsi komisaris independen dan komite audit masing-masing memiliki t-statistics sebesar 2,323; 2,731 > 1,66 artinya signifikan $\left(\mathrm{H}_{12} ; \mathrm{H}_{17}\right.$ diterima, dengan masingmasing sig. 0,023 dan 0,008). Nilai t-statistics atas DER terhadap EBT sebesar -0,561 (sig. 0,576), artinya tidak berpengaruh signifikan $\left(\mathrm{H}_{3}\right.$ ditolak) sementara DER terhadap EBT dengan moderasi variabel kepemilikan manajerial memiliki t-statistics sebesar 0,658 artinya juga tidak signifikan $\left(\mathrm{H}_{8}\right.$ ditolak) karena kurang dari t-table. Di sisi lain, DER terhadap EBT dengan moderasi variabel proporsi komisaris independen dan komite audit masing-masing memiliki t-statistics sebesar -0,457; $-0,518<1,66$ artinya tidak signifikan $\left(\mathrm{H}_{13} ; \mathrm{H}_{18}\right.$ ditolak, dengan masing-masing sig. 0,649 dan 0,606). Nilai t-statistics atas TATO terhadap EBT sebesar -1,674 (sig. 0,006), artinya berpengaruh signifikan $\left(\mathrm{H}_{4}\right.$ diterima) sementara TATO terhadap EBT dengan moderasi variabel kepemilikan manajerial memiliki t-statistics sebesar -1,949 artinya signifikan ( $\mathrm{H}_{9}$ diterima) karena lebih dari t-table. Di sisi lain, TATO terhadap EBT dengan moderasi variabel proporsi komisaris independen dan komite audit masingmasing memiliki t-statistics sebesar -1,529; -1,229 < 1,66 artinya tidak signifikan $\left(\mathrm{H}_{14} ; \mathrm{H}_{19}\right.$ ditolak, dengan masing-masing sig. 0,130 dan 0,223). Nilai t-statistics atas EPS terhadap EBT sebesar -0,724 (sig. 0,471), artinya tidak berpengaruh signifikan ( $\mathrm{H}_{5}$ ditolak) sementara EPS terhadap EBT dengan moderasi variabel kepemilikan manajerial memiliki t-statistics sebesar 1,744 artinya signifikan $\left(\mathrm{H}_{10}\right.$ diterima) karena lebih dari t-table. Di sisi lain, EPS 
terhadap EBT dengan moderasi variabel proporsi komisaris independen dan komite audit masing-masing memiliki t-statistics sebesar -0,675; -0,824 < 1,66 artinya tidak signifikan $\left(\mathrm{H}_{15} ; \mathrm{H}_{20}\right.$ ditolak, dengan masing-masing sig. 0,502 dan 0,413).

\section{Pembahasan}

ROE digunakan untuk mengukur keefektifan perusahaan dalam menggunakan modal yang tersedia. Perusahaan yang memiliki ROE yang tinggi memungkinkan perusahaan untuk menghasilkan profit yang lebih di masa yang akan datang. Kepemilikan Manajerial (KMJ) tidak mampu memoderasi baik memperkuat maupun memperlemah rasio profitabilitas (ROE) terhadap profit growth, temuan ini sesuai dengan penelitian yang dilakukan oleh (Arshad \& Javid, 2014), bahwa kepemilikan manajerial tidak signifikan berpengaruh terhadap kinerja perusahaan yang diukur dengan ROE dan ROA, hasil ini juga berlawanan dengan agency theory yang menyatakan bahwa kepemilikan manajerial akan mengurangi asimetri informasi karena manajemen akan mengambil keputusan untuk kepentingan pemegang saham. Komisaris Independen (KMI) tidak mampu memoderasi rasio profitabilitas (ROE), kehadiran komisaris independen memiliki salah satu peran yaitu untuk melindungi pemegang saham minoritas yang tidak berdaya untuk mengambil tindakan di saat hak mereka dilanggar oleh pemegang saham mayoritas (Setiawan, Junarsin, \& Yuliati, 2013). Komite Audit (KAT) mampu memoderasi dengan memperlemah rasio profitabilitas (ROE) terhadap profit growth, penelitian ini telah membuktikan penelitian sebelumnya yaitu (Chong, Ting, \& Fah Fah, 2018) yang menyatakan bahwa tata kelola perusahaan dapat menjadi moderator positif atau negatif yang dapat meningkatkan dan mempercepat kinerja, return on assets, return on equity dan Real Estate Investment Trust (REIT) return dan mengurangi biaya keagenan.

Rasio likuiditas (CR) secara signifikan berpengaruh positif terhadap profit growth, artinya perusahaan yang likuid dapat memutar modal kerja dalam jangka pendek lebih baik untuk menyelesaikan kewajiban jangka pendek dan kebutuhan operasional jangka pendek sehingga meningkatkan pertumbuhan laba. Kepemilikan Manajerial (KMJ) tidak mampu memoderasi baik memperkuat maupun memperlemah rasio likuiditas (CR) terhadap profit growth, hasil penelitian ini sama dengan hasil penelitian yang dilakukan oleh (Papaioannou, Strock, \& Travlos, 1992) bahwa pemegang saham yang merupakan manajemen dalam suatu perusahaan dengan kepemilikan saham yang rendah memiliki insentif untuk mengurangi risiko atas pengembalian aset untuk meningkatkan gaji manajemen tersebut. Komisaris Independen (KMI) tidak mampu memoderasi rasio likuiditas (CR), dimana kehadiran komisaris independen memiliki salah satu peran yaitu untuk melindungi pemegang saham minoritas 
yang tidak berdaya untuk mengambil tindakan di saat hak mereka dilanggar oleh pemegang saham mayoritas (Setiawan, Junarsin, \& Yuliati, 2013). Komite Audit (KAT) mampu memoderasi dengan rasio likuditas (CR) terhadap profit growth, penelitian ini telah membuktikan penelitian sebelumnya yaitu (Chong, Ting, \& Fah Fah, 2018). Kehadiran komite audit (KAT) memang dapat meningkatkan kualitas pelaporan informasi keuangan walaupun dengan fungsi memperlemah dikarenakan pertumbuhan industri manufaktur makanan dan minuman yang mengalami trend menurun pada periode pengamatan.

Leverage ratio (DER) berpengaruh tidak signifikan terhadap profit growth, hal ini disebabkan oleh pertumbuhan penjualan manufaktur makanan pada tahun 2017 hanya tumbuh 2,7\% dibandingkan pertumbuhan 11\% Compound Annual Growth Rate (CAGR) dari tahun 2003 hingga 2017 (Muamar, 2018). DER yang tinggi menimbulkan cost of debt yang meningkat seiring dengan peningkatan pendapatan berasal dari penggunaan utang tersebut. Penggunaan utang sebagai sumber pembiayaan dapat menjadi umpan balik negatif jika tidak ada pertumbuhan laba untuk lebih besar daripada bunga utang. Kepemilikan Manajerial (KMJ), Proporsi Komisaris Independen (KMI) dan Komite Audit (KAT) tidak mampu memoderasi baik memperkuat maupun memperlemah leverage ratio (DER) terhadap profit growth. Berdasarkan penelitian yang dilakukan oleh (Arshad \& Javid, 2014), meningkatnya kepemilikan manajerial dapat mengurangi kecenderungan perusahaan untuk melakukan pendaanaan melalui utang. Manajemen tersebut akan memilih sumber pendanaan lain atau menggunakan modal kerja yang ada sehingga kesempatan ekspansi berkurang karena keterbatasan modal yang digunakan walaupun terdapat kesempatan untuk meningkatkan pertumbuhan. Keputusan terkait pendanaan merupakan bagian dari operasional perusahaan dan menjadi tanggung jawab Direksi. Dari hasil penelitian ini, dapat dilihat bahwa asimetri informasi memang terjadi meskipun telah ada pengawasan dari komisaris independen. Kehadiran Komite Audit (KAT) juga tidak dapat memastikan bahwa manajemen mengambil keputusan pendanaan sesuai dengan kepentingan pemegang saham. Peran dari Komite Audit terbatas pada melakukan manajemen risiko, evaluasi dan pemeriksaan atas keputusankeputusan yang telah diambil oleh manajemen komite audit tidak terlibat langsung dalam proses pembuatan keputusan yang dilakukan oleh manajemen sehingga komite audit tidak mampu berfungsi antara leverage rasio (DER) terhadap profit growth.

Rasio aktivitas (TATO) secara signifikan berpengaruh negatif terhadap profit growth, artinya semakin tinggi TATO maka semakin tinggi penjualan dan keuntungan yang dihasilkan. Kepemilikan manajerial (KMJ) juga mampu memperlemah rasio aktivitas (TATO) terhadap profit growth, Hasil ini sesuai dengan penelitian yang dilakukan oleh Lim et al (2007) dalam 
(Arshad \& Javid, 2014) yang meneliti tentang hubungan kepemilikan manajerial dengan kinerja perusahaan dan menemukan bahwa perusahaan dengan kepemilikan manajerial memiliki pengendalian yang lebih baik antara pertumbuhan aset terhadap pertumbuhan penjualan. Proporsi Komisaris Independen (KMI) dan Komite Audit (KAT) tidak mampu memoderasi baik memperkuat maupun memperlemah rasio aktivitas (TATO) terhadap profit growth, hal ini menandakan bahwa keputusan terkait pendanaan merupakan bagian dari operasional perusahaan dan menjadi tanggung jawab Direksi. Dari hasil penelitian ini, dapat dilihat bahwa asimetri informasi memang terjadi meskipun telah ada pengawasan dari komisaris independen dan komite audit (KAT) juga tidak terlibat langsung dalam proses pembuatan keputusan yang dilakukan oleh manajemen.

Rasio pasar modal (EPS) tidak berpengaruh yang terhadap profit growth. EPS yang merupakan salah satu ukuran mendasar dalam keuangan perusahaan. Rasio ini merupakan pengujian yang tepat untuk menguji kemampuan perusahaan dalam memperoleh keuntungan yang diperoleh untuk setiap saham perusahaan. Dalam penelitian ini, EPS pada perusahaan Manufaktur Sektor 5 terus mengalami penurunan pada periode pengamatan yaitu 2015-2017. Kepemilikan Manajerial (KMJ) mampu memperkuat hubungan rasio pasar modal (EPS) terhadap profit growth, hasil penelitian ini sesuai dengan hasil penelitian (Papaioannou, Strock, \& Travlos, 1992) bahwa pemegang saham yang merupakan manajemen dalam suatu perusahaan dengan kepemilikan saham yang rendah memiliki insentif untuk mengurangi risiko atas pengembalian aset untuk meningkatkan gaji manajemen tersebut. Seiring dengan peningkatan kepemilikan manajerial, kekayaan pemegang saham tersebut bergantung pada harga saham dan selanjutnya akan mengikuti kebijakan yang mengarah pada maksimalisasi nilai perusahaan yang sering diukur dengan harga per saham (EPS). Proporsi Komisaris Independen (KMI) dan Komite Audit (KAT) tidak mampu memoderasi baik memperkuat maupun memperlemah rasio pasar modal (EPS) terhadap profit growth, hal ini menandakan bahwa kehadiran komisaris independen dalam perusahaan akan mengurangi kemungkinan financial distress kemudian perusahaan yang memiliki komite audit cenderung tidak terlibat dalam memanipulasi laba sehingga menghasilkan informasi keuangan yang berkualitas (Martinov Bennie, Soh, \& Tweedie, 2015), yang juga tidak dapat memastikan bahwa manajemen mengambil keputusan pendanaan sesuai dengan kepentingan pemegang saham pada saat keputusan diambil. Peran dari komite audit hnaya terbatas pada melakukan manajemen risiko, evaluasi dan pemeriksaan atas keputusan-keputusan yang telah diambil oleh pihak manajemen. 


\section{KESIMPULAN DAN IMPLIKASI}

\section{Kesimpulan}

Berdasarkan pembahasan secara komprehensif, maka penelitian ini dapat disimpulkan bahwa rasio profitabilitas (ROE), rasio likuiditas (CR) dan rasio aktivitas (TATO) berpengaruh signifikan terhadap profit growth sementara leverage ratio (DER) dan rasio pasar modal (EPS) tidak berpengaruh signifikan terhadap profit growth.

Rasio profitabilitas (ROE) tidak dimoderasi oleh kepemilikan manajerial dan proporsi komisaris independen sementara dimoderasi oleh komite audit dalam hubungannya terhadap profit growth. Rasio likuiditas (CR) tidak dimoderasi oleh kepemilikan manajerial sementara dimoderasi oleh proporsi komisaris independen dan komite audit dalam hubungannya terhadap profit growth. Leverage ratio (DER) tidak dimoderasi oleh baik kepemilikan manajerial, proporsi komisaris independen dan komite audit dalam hubungannya terhadap profit growth. Rasio aktivitas (TATO) dimoderasi oleh kepemilikan manajerial dan komite audit sementara tidak dimoderasi oleh proporsi komisaris independen dalam hubungannya terhadap profit growth. Rasio pasar modal (EPS) hanya dimoderasi oleh kepemilikan manajerial sementara tidak dimoderasi oleh proporsi komisaris independen dan komite audit dalam hubungannya terhadap profit growth.

\section{Implikasi Penelitian}

Beberapa variabel mampu manjadi variabel sesuai dengan fungsinya yaitu adanya kemampuan memoderasi, maka kepada fund manager hendaknya memperhatikan kondisi ini dengan cara melalukan pengamatan dan penekanan bahwa kepemilikan manajerial, komisaris independen dan komite audit hendaknya menjadi strategi dalam pengelolaan keuangan di masa kini dan masa yang akan datang. Asimetri informasi masih terjadi meskipun telah ada pengawasan dari komisaris independen. Penelitian selanjutnya dapat memperdalam secara empiris faktor-faktor yang dapat memperkecil asimetri informasi dengan dimoderasi oleh unsur-unsur tata kelola yang baik. ROE, CR, DER, TATO, dan EPS hanya mampu menjelaskan EBT sebesar 23,3 persen, sehingga sisanya 76,7 persen dijelaskan oleh faktor lain seperti ukuran perusahaan, jenis industri, tingkat inflasi, diferensiasi produk, reputasi dan kondisi ekonomi makro lainnya Dengan demikian, peneliti selanjutnya dapat menggunakan faktor-faktor lain yang lebih mempengaruhi proksi EBT.

\section{DAFTAR PUSTAKA}


Ak, B. K., Dechow, P. M., Sun, E., \& Wang, A. (2013). The Use of Financial Ratio Models to Help Investors Predict and Interpret Significant Corporate Events. Australian Journal of Management, 553-598, 553-598. doi:10.2139/ssrn.2335185

Al Attar, M. (2016). The Impact of Investing Environment on Financial Performance. International Research Journal of Applied Finance, 7(8), 172-178. doi:10.0708/article-2

Antara. (2018, November 18). Indeks Manajer Pembelian Naik, Apindo: Manufaktur Kian Bergairah. (K. Setiawan, Editor) Retrieved Desember 24, 2020, from Bisnis Tempo.Co: https://bisnis.tempo.co/read/1127202/indeks-manajer-pembelian-naikapindo-manufaktur-kian-bergairah/full\&view=ok

Arshad, H., \& Javid, A. Y. (2014). Does Inside Ownership Matters in Financial Decisions and Firm Performance: Evidence from Manufacturing Sector of Pakistan. St.Louis: IDEAS Working Paper Series from RePEc. Retrieved from Does Inside Ownership Matters in Financial Decisions and Firm Performance: Evidence from Manufacturing Sector of Pakistan

Bansal, R. (2015). A comparative analysis of the financial performances of selected indian IT companies during 2010-2014. IUP Journal of Accounting Research \& Audit Practices, 14(4), 43-60.

Batchimeg, B. (2017). Financial Performance Determinants of Organizations The Case of Mongolian Companies. Journal of Competitiveness, 9(3), 22-33. doi:10.7441/joc.2017.03.02

Chong, W., Ting, K., \& Fah Fah, C. (2018). The Impact Of Corporate Governance Moderating Effects On The Performance OF REITS In Asia. Journal of Real Estate Literature, 26(1), 151-174.

Daniel, G. A. (2015). Consensus on Commonly used Financial Ratios. In J. Velencei (Ed.), Proceedings of FIKUSZ '15: Symposium for Young Reseachers (pp. 79-88). Budapest: Keleti Faculty of Business and Management, Óbuda University.

Darmadi, T., \& Fakhrudin, M. H. (2006). Pasar Modal di Indonesia. Jakarta: Salemba Empat.

Dholakia, R. R., \& Uusitalo, O. (2002). Switching to electronic stores: consumer characteristics and the perception of shopping benefits. International Journal of Retail \& Distribution Management, 30(1), 459-469. doi:10.1108/09590550210445335

Driharsanto, C., \& Husain, T. (2016). Pengaruh Mekanisme Corporate Governance dan Profitabilitas terhadap Cost-of Debt. JEMBATAN, 2(1), 18-32.

Fransisca, M. (2013). Analisis Pengaruh Board of Director Diversity terhadap Kinerja Perusahaan dalam Perspektif Corporate Governance (Studi Empiris pada Perusahaan Manufaktur yang Terdaftar di Bursa Efek Indonesia Tahun 2011). Jakarta: Universitas Indonesia Library.

Godfrey, J., Hodgson, A., Tarca, A., Hamilton, J., \& Holmes, S. (2010). Accounting Theory ( $7^{\text {th }}$ Ed.). Australia: John Willey \& Sons, Inc.

Gunawan, A. (2018, Februari 27). Unilever Taklukkan Pelemahan Konsumsi Lewat Efisiensi. Retrieved December 22, 2020, from CNBC Indonesia: https://www.cnbcindonesia.com/market/20180227191200-17-5673/unilevertaklukkan-pelemahan-konsumsi-lewat-efisiensi

Gupta, S. (2012). Analysis of leverage ratio in selected Indian Public Sector and Private Sector Banks. Asian Journal of Management Research, 12-19. 
Herawati, A. (2017). The Factors Affecting Initial Return on IPO Company in IDX 2007 2012. International Journal of Economic Perspectives, 11(1), 1499-1509.

Hery. (2013). Rahasia Pembagian Deviden \& Tata Kelola Perusahaan. Yogyakarta: Penerbit Gava Media.

Husain, T. (2019). An Analysis of Modeling Audit Quality Measurement Based on Decision Support Systems (DSS). European Journal of Scientific Exploration, 2(6), 1-9.

Husain, T., \& Syniuta, A. (2020). Audit Fee and "The Big-Four": A Comparative Study at Initial Public Offerings (IPO) Companies in Indonesia Stock Exchange (IDX). Multidisciplinary European Academic Journal, 2(4), 1-7.

Jensen, M. C., \& Meckling, W. H. (1976). Theory of the firm: Managerial behavior, agency costs and ownership structure. Journal of Financial Economics, 3(4), 305-360. doi:10.1016/0304-405X(76)90026-X

Kementerian Perindustrian RI. (2018, Mei 26). Investasi Manufaktur Tembus Rp 63 Triliun, Ekspor Naik Jadi USD 32 Miliar. Retrieved Desember 24, 2020, from SIARAN PERS: https://kemenperin.go.id/artikel/19290/Investasi-Manufaktur-Tembus-Rp-63Triliun,-Ekspor-Naik-Jadi-USD-32-Miliar

Khan, M. A., \& Ibrahim, M. Y. (2017). Improving Financial Performance Through Corporate Governance Mechanism in Malaysia Listed Companies: Empirical Study Approach. Global Business \& Management Research, 9(1s), 28-38.

Lim, A., \& Rice. (2016). Analisa Faktor-Faktor yang Mempengaruhi Pertumbuhan Laba Dengan Ukuran Perusahaan Sebagai Variabel Moderating pada Perusahaan Manufaktur yang Terdaftar di Bursa Efek Indonesia. Jurnal Wira Ekonomi Mikroskil, 6(01), 85-101.

Martinov Bennie, N., Soh, D., \& Tweedie, D. (2015). An investigation into the roles, characteristics, expectations and evaluation practices of audit committees. Managerial Auditing Journal, 727-755. Retrieved from https://search.proquest.com/docview/1712468575 ?accountid=17242

Muamar, Y. (2018, November 18). Pertumbuhan Industri Barang Konsumsi Dinilai Melambat. Retrieved Desember 20, 2020, from CNBC Indonesia: https://www.cnbcindonesia.com/market/20181019191302-17-38252/pertumbuhanindustri-barang-konsumsi-dinilai-melambat

OECD. (2017). OECD Corporate Governance Factbook (updated as of end 2016). Paris: Organisation for Economic Co-Operation and Development. Retrieved from https://www.oecd.org/daf/ca/OECD-Corporate-Governance-Factbook-2017.pdf

OJK. (2014). Roadmap Tata Kelola Perusahaan Indonesia. Jakarta: Otoritas Jasa Keuangan. Retrieved Februari 15, 2016, from https://www.ifc.org/wps/wcm/connect/a476310042e2a54bbc09fc384c61d9f7/Indones ia+CG+Roadmap.pdf?MOD=AJPERES

OJK. (2015). Peraturan Otoritas Jasa Keuangan (OJK) Nomor 21/POJK.04/2015 tentang Penerapan Pedoman Tata Kelola Perusahaan Terbuka. Jakarta: Otoritas Jasa Keuangan.

Panglipurningrum, Y. S., \& Husain, T. (2021). Determinan Keterlambatan Pelaporan Audit Pada Perusahaan Yang Melakukan IPO (Initial Public Offerings). ProBank, 6(1), 8088. doi:10.36587/probank.v6i1.846 
Papaioannou, G., Strock, E., \& Travlos, N. (1992). Ownership Structure and Corporate Liquidity Policy. Managerial and Decision Economic, 3(4), 315. Retrieved from https://search.proquest.com/docview/230014668? accountid=17242

Paramaesti, C. (2018, November 18). Industri Makanan dan Minuman Tumbuh 8,67 Persen Triwulan II 2018. Retrieved Desember 20, 2020, from Bisnis Tempo.Co: https://bisnis.tempo.co/read/1127039/industri-makanan-dan-minuman-tumbuh-867persen-triwulan-ii-2018/full\&view $=$ ok

Pasupati, B. (2020). Pengaruh Rasio Profitabilitas Terhadap Perubahan Laba. Jurnal Buana Akuntansi, 5(2), 1-12. doi:10.36805/akuntansi.v5i2.1114

Pasupati, B., \& Husain, T. (2020). COVID-19 Pandemic: Audit Delay and Reporting in Indonesian. Research Inventy: International Journal of Engineering And Science, 10(11), 08-11.

Pertiwi, D. S. (2018, Juli 10). Peringkat ASEAN Corporate Governance Scorecard (ACGS). Retrieved Januari 11, 2021, from Newsroom: RSM International Association: https://www.rsm.global/indonesia/en/news/peringkat-asean-corporate-governancescorecard-acgs

Putra, A. P., Lahindah, L., \& Rismandi, B. (2014). Financial Performance Analysis Before and After Global Crisis (Case Study in Indonesian Oil and Gas Sector for the Period of 2006-2011). Review of Integrative Business and Economics Research, 3(1), 42-51.

Putra, M. P., Mahaputra, I. A., \& Pasupati, B. (2021). Determinan Faktor Yang Mempengaruhi Praktik Perataan Laba Pada Perusahaan Manufaktur Yang Terdaftar Di Bursa Efek Indonesia. AKBIS: Media Riset Akuntansi dan Bisnis, 5(1), 33-50. doi:10.35308/akbis.v5i1.3559

Ridwan, \& Husain, T. (2017). Pengaruh Independensi, Pengalaman, Dan Pertimbangan Profesional Auditor Terhadap Kelengkapan Bahan Bukti Audit. MABISKA Journal, 2(1), 1-15.

Saragih, H., \& Husain, T. (2012). Pengaruh Fitur-Fitur Blog terhadap Continuance Intention to Visit Blogs pada Toko Online Multiply. Journal of Computer Information, 1(1), 518.

Sari, F. (2018). Metode dalam Pengambilan Keputusan ( $1^{\text {st }}$ Ed.). Sleman: Deepublish (CV. Budi Utama).

Sarwani, \& Husain, T. (2021). The Firm's Value Empirical Models in Automotive and Components Subsectors Enterprises: Evidence from Developing Economy. Journal of Governance and Regulation, 10(1), 83-95. doi:10.22495/jgrv10i1art9

Scott, W. R. (2015, February). Financial Accounting Theory ( $7^{\text {th }}$ Ed.). New Jersey: PrenticeHall International, Inc.

Sugiyono. (2017). Metode Penelitian Evaluasi: Pendekatan Kuantitatif, Kualitatif, dan Kombinasi. Bandung: CV. Alfabeta.

Sulistyanto, H. (2014). Manajemen Laba: Teori dan Model Empiris (Vol. II). (M. Listyandari, Ed.) Jakarta: Grasindo.

Supranto, J., \& Limakrisna, N. (2019). Petunjuk Praktis Penelitian Ilmiah untuk Menyusun Skripsi, Tesis dan Disertasi ( $5^{\text {th }}$ Ed.). Bogor: Penerbit Mitra Wacana Media.

Tuasikal, A. (2002). Penggunaan Informasi Akuntansi untuk Memprediksi Return Saham: Studi terhadap Perusahaan Pemanufakturan dan non-Pemanufakturan. The Indonesian Journal of Accounting Research (IJAR), 5(3). doi:10.33312/ijar.87 
Veronica, M. S., \& Anantadjaya, S. P. (2014). Bankruptcy Prediction Model: An Industrial Study in Indonesian Publicly-listed Firms During 1999-2010. Review of Integrative Business and Economic Research, 3(1), 13-41.

Yunita, N. (2012). Pengaruh Corporate Governance terhadap Voluntary Disclosure dan Biaya Hutang. Jurnal Ilmiah Mahasiswa Akuntansi, 1(1), 90-96. doi:10.33508/jima.v1i1.18

Zagorchev, A., \& Gao, L. (2015). Corporate Governance and Performance of Financial Institutions. Journal of Economics and Business, 82(C), 17-41. doi:10.1016/j.jeconbus.2015.04.004

Zailani, A. U., Husain, T., \& Budiyantara, A. (2020). Analisis Simulasi Sistem Penunjang Keputusan: Model Matematis Dengan Pendekatan Goodness-of Fit Berbasis Structural Equation Model. SMARTICS Journal, 6(1), 10-16. doi:10.21067/smartics.v6i1.4157 